\title{
UNA PROPUESTA DE ATRIBUCIÓN DEL RETABLO MAYOR DE LA CAPILLA DE SAN JOSÉ DE SEVILLA A FRANCISCO DE ACOSTA EL MAYOR
}

\author{
AN ATTRIBUTION PROPOSAL OF THE MAIN \\ ALTARPIECE AT SEVILLIAN SAINT JOSEPH CHAPEL TO \\ FRANCISCO DE ACOSTA THE ELDER
}

\author{
Álvaro Recio Mir \\ Universidad de Sevilla. España \\ ORCID: 0000-0001-7874-5625 \\ alvarorecio@us.es
}

\begin{abstract}
Propuesta de atribución del retablo mayor de la capilla de San José, del gremio de carpinteros de Sevilla, a Francisco de Acosta el Mayor, primogénito y heredero artístico de Cayetano de Acosta, que en esta obra, que creemos levantada hacia 1765-1770, logró una de las cumbres del rococó hispalense.

Palabras clave: Francisco de Acosta el Mayor; retablo; rococó; Sevilla; capilla de San José.
\end{abstract}

This paper make an attribution proposal of the main altarpiece of the Saint Joseph Chapel, of the carpenters' union of Seville, to Francisco de Acosta the Elder, first-born and artistic inheritor of Cayetano de Acosta, who in this work, which we believe raised towards 1765-1770, achieved one of the summits of the Sevillian rococo.

Keywords: Francisco de Acosta the Elder; altarpiece; Rococo; Seville; Saint Joseph Chapel.

El gran artífice del retablo rococó en Sevilla fue indudablemente Cayetano de Acosta, de manera que su estela fue seguida por los viejos maestros que hasta entonces habían practicado el retablo de estípites y desarrollada con entusiasmo por los jóvenes maestros ya formados en el rococó, ejemplo de lo cual fueron Felipe Fernández del Castillo, Manuel García de Santiago, Juan Cano, Julián Jiménez o Manuel Barrera y Carmona. El liderazgo de Acosta se basó tanto en una arrolladora capacidad creativa como en un potente taller de carácter familiar. En tal sentido, es muy significativo que en los pagos por las labores decorativas en piedra y yeso que realizó en la Real Fábrica de Tabacos de Sevilla se aludiese explícitamente a "don Cayetano y sus hijos". Por desgracia, aún no sabemos demasiado 
de esta numerosa prole de artistas, pero todo parece indicar que el más importante de los hijos de Acosta fue el primogénito, Francisco el Mayor, nacido en Sevilla en 1734 y que lógicamente se formó con su padre. Él fue el principal retablista de la ciudad en la década de los años ochenta del siglo XVIII, tras la muerte de Cayetano en 1778, al que también sustituyó como maestro mayor de talla del arzobispado. De hecho, Francisco de Acosta el Mayor fue testigo del agotamiento del rococó y ya anunció el neoclasicismo antes de fallecer en $1789^{1}$.

Su primera obra documentada y conservada es el retablo mayor que contrató en 1770 para el desaparecido convento del Carmen Calzado de Carmona. En concreto, Francisco de Acosta el Mayor, actuando como fiador su padre, se obligó a hacerlo por 26.000 reales. Esta importante obra, apenas conocida, se encuentra en la actualidad en la capilla de la Fundación San Telmo de Sevilla, donde fue instalada a principios del siglo XX cuando el edificio era Casa Cuna. El retablo, que quedó en blanco, sobresale por el virtuosismo en su talla y por las rocallas verdaderamente definitivas con las que cuenta. Lo articulan cuatro potentes estípites y lo centra una gran hornacina que se proyecta en el espacio y se abre como una teatral embocadura de filiformes soportes y quebradas cornisas ${ }^{2}$.

En 1772 Francisco de Acosta el Mayor, de nuevo con su padre como fiador, se comprometió a realizar dos retablos colaterales para la capilla mayor de la misma iglesia, "para concurrir por este medio al culto a Dios debido". Cada uno fue tasado en este caso en 15.000 reales $^{3}$. Uno de estos retablos, que sigue en todo las pautas del mayor antes referido, lo identificamos recientemente con el

${ }^{1} \mathrm{Su}$ trayectoria es analizada en RECIO MIR, Álvaro: "El brillante final del barroco: el retablo rococó", en HALCÓN, Fátima; HERRERA, Francisco y RECIO, Álvaro: El retablo sevillano. Desde sus origenes a la actualidad. Sevilla, 2009, pp. 364-368. Sobre su padre es esencial PLEGUEZUELO HERNÁNDEZ, Alfonso: Cayetano de Acosta. Sevilla, 2007. Sobre la familia de Cayetano de Acosta remitimos a PLEGUEZUELO HERNÁNDEZ, Alfonso: "Un retrato familiar de los Acosta en su segunda fase sevillana y algunas nuevas atribuciones", Laboratorio de arte, 7, 1994, pp. 131-159; y ROS GONZÁLEZ, Francisco S.: Noticias de escultura (1781-1800). Sevilla, 1999, ad vocem.

${ }^{2}$ El documento fue publicado en MIRA CABALLOS, Esteban y DE LA VILLA NOGALES, Fernando: Carmona en la Edad Moderna. Religiosidad y arte, población y emigración a América. Sevilla, 1999, pp. 133-134. El retablo fue dado a conocer y atribuido a Francisco de Acosta el Mayor en RECIO MIR, Álvaro: "El retablo rococó", en HALCÓN, Fátima; HERRERA, Francisco y RECIO, Álvaro: El retablo barroco sevillano. Sevilla, 2000, pp. 202-203. Por último, fue identificado como el mayor de los levantados en el Carmen Calzado de Carmona en HERRERA GARCÍA, Francisco Javier: "El retablo en Carmona durante la segunda mitad del siglo XVIII”, en GONZÁLEZ JIMÉNEZ, Manuel (ed.): Carmona en la Edad Moderna. III congreso de Historia de Carmona. Carmona, 2003, pp. 232-233.

3 MIRA CABALlOS, Esteban y DE LA VILLA NOGALES, Fernando: Carmona en la Edad Moderna..., op. cit., pp. 134-135. 
que preside la capilla del colegio de la Sagrada Familia de Sevilla ${ }^{4}$. Por evidentes cuestiones estilísticas, Francisco Herrera identificó como obra del mismo autor y también procedente del referido convento de Carmona el retablo que actualmente preside la iglesia de San Francisco en la localidad sevillana de Fuentes de Andalucía, aunque todo parece indicar que no es referido en ninguno de los dos contratos citados 5 .

Por su estrecha relación con las anteriores obras, le atribuimos a Francisco de Acosta el Mayor el retablo de la Virgen del Rosario de la iglesia de San Jacinto de Sevilla, que cabe fechar hacia 1775, momento en el que sabemos que fue concluida la fábrica de dicho templo. Se trata de un retablo camarín y transparente, que se expande en la arquitectura de la capilla, cuajada de yeserías de rocallas doradas, el cual, a pesar de la innegable relación que presenta con las obras anteriores, muestra ya una cierta aminoración decorativa ${ }^{6}$ (Figura 1).

También le hemos atribuido el que fuera retablo mayor de la sevillana parroquia de Santa Lucía, que en la actualidad preside la nave de la epístola de la iglesia del Salvador y del que solo sabemos que ya estaba terminado en 1779. A pesar de las transformaciones que ha sufrido con posterioridad esta maltratada obra y aunque sus soportes son columnas clásicas, aún atisbamos en él la creatividad de Acosta el Mayor, tanto en su potente y dislocada cornisa, como en algunos golpes de talla que configuran grandes rocallas similares a las que aparecen en los anteriores retablos ${ }^{7}$.

El giro hacia el neoclasicismo se evidencia en su trayectoria en los retablos de la capilla del palacio arzobispal de Sevilla, contratados por Acosta el Mayor en 1781. El retablo mayor, completamente desornamentado, tiene una estructura trepidante, con columnas clásicas que se disponen en diversos planos y que responde a los modelos del barroco internacional. Por su parte, su policromía simula mármoles de colores y bronce dorado. En cambio, los cuatro retablos laterales, a pesar de tener también como soportes columnas clásicas, muestran un mayor apego al barroco ${ }^{8}$.

${ }^{4}$ RECIO MIR, Álvaro y MARISCAL RODRÍGUEZ, Miguel Á.: "El triunfo de la rocalla: el retablo de la capilla del colegio Sagrada Familia de Sevilla, obra de Francisco de Acosta el Mayor", Laboratorio de arte, 29, 2017, pp. 827-836.

${ }_{5}^{5}$ HERRERA GARCÍA, Francisco Javier; QUILES GARCÍA, Fernando y SAUCEDO PRADAS, Consuelo: Carmona barroca. Panorama artístico de los siglos XVII y XVIII. Sevilla, 1997, pp. 88-89.

${ }^{6}$ RECIO MIR, Álvaro: "El retablo rococó", op. cit., p. 203.

7 Esta atribución la realizamos en RECIO MIR, Álvaro: "Los retablos: de los Terceros al Salvador", en RODRÍGUEZ BABÍO, Amparo (coord.): Amor (1618-2018). Sevilla, 2018, p. 206.

${ }^{8}$ FALCÓN MARQUEZ, Teodoro: El Palacio Arzobispal de Sevilla. Córdoba, 1997, p. 117. 
En este marco, proponemos una nueva atribución a la actividad artística de Acosta el Mayor: el retablo mayor de la capilla de San José de Sevilla, que fue del gremio de carpinteros de lo blanco ${ }^{9}$. Se trata de una obra que ha generado un cierto debate historiográfico, lo que pone de manifiesto su gran significación. El primero que se ocupó de este retablo con algún detalle fue Antonio Sancho Corbacho, que lo relacionó de forma pionera con Cayetano de Acosta, y que lo dató, a partir de documentación inédita, entre 1762 y $1766^{10}$. Por su parte, Antonio Bonet Correa apuntó que la obra cumbre de Cayetano de Acosta fue el retablo-portada de la capilla sacramental del Salvador, añadiendo significativamente que sus superlativos valores "sólo [los] superan obras tan logradas como el retablo de la capilla de San José, que acertadamente le atribuye Sancho Corbacho"11.

En fechas más recientes Alfonso Pleguezuelo ha insistido en la importancia de esta obra y ha advertido cuán confusos son los datos que conocemos de su hechura. Aunque mantiene la referida atribución, reconoce que la talla ornamental de este retablo muestra en su manifestador rasgos algo diferentes al estilo de Cayetano de Acosta, pero piensa que solo él pudo trazarlo, apuntando que de su ejecución podría haberse ocupado Julián Jiménez entre 1757 y 1766 . Dice también de su ensambladura que, junto con la del retablo-portada de la capilla sacramental del Salvador, son "las estructuras más atrevidas de la retablística andaluza del momento". En concreto, del caso que nos ocupa, destaca el vigor de su diseño, tanto de la obra en general como de sus detalles particulares, y la destreza en la difícil manipulación de tantísimos elementos quebrados y proyectados en las tres dimensiones del espacio ${ }^{12}$.

Por mi parte, ya señalé que la autoría de este retablo es la gran incógnita del retablo rococó sevillano y puse en duda su atribución a Cayetano de Acosta, la más extendida hasta ahora por parte de la historiografía, ya que como he explicado -y abundaré en esta ocasión- no veo en él concomitancias con su estilo. Por ello preferí relacionarlo más con Julián Jiménez o, ante las reservas que ello sinceramente también me planteaba, tenerlo como una obra quizá coral, en la que pudieron intervenir varios autores, incluso el propio gremio de carpinteros que a la postre fue quien lo encargó ${ }^{13}$.

9 Sobre la misma remitimos a CRUZ ISIDORO, Fernando: La capilla de San José del gremio de carpinteros de lo blanco. Sevilla, 2015.

${ }^{10}$ SANCHO CORBACHO, Antonio: Arquitectura barroca sevillana del siglo XVIII. Madrid, 1984, pp. 290-291.

11 BONET CORREA, Antonio: Andalucía barroca. Arquitectura y urbanismo. Barcelona, 1978, pp. 186 y 192.

12 PLEGUEZUELO, Alfonso: Cayetano de Acosta..., op. cit., pp. 109-115.

13 RECIO MIR, Álvaro: "El retablo rococó", op. cit., pp. 263-264; y RECIO MIR, Álvaro: "El brillante final del barroco...", op. cit., p. 357. 
Las anteriores dudas son debidas a que la documentación aparecida hasta ahora en relación a este retablo es tan parca como compleja. Su historia material cabe retrotraerla a la década de los años cincuenta del siglo XVIII, ya que en 1750 se decidió vender el viejo retablo y hacerle un camarín al San José que lo preside. En esa década de los años cincuenta se fecha un proyecto para esta obra del pintor Pedro del Pozo, del que se dice, como documentó Herrera, que era "fuera de lo común", ya que carecía de soportes, a lo que añadía que era de "arquitectura y cornisas, aunque no estípites ni columnas, porque no las necesita, porque sin esta circunstancia está hermoso"14. En relación con ello Pleguezuelo puso de manifiesto lo sorprendente que resulta que un modesto pintor como Pedro del Pozo llevara a cabo un proyecto de retablo tan poco habitual en Sevilla y añadió, a partir de documentación inédita, que en 1757 el gremio de carpinteros acordó preguntar a "don Julián Jiménez para que diga en el que tanto que se determina a ejecutar el retablo mayor según el dibujo [que] tiene fecho"15.

Desde ese momento carecemos de datos fehacientes sobre la construcción del retablo, hasta que entre 1777 y 1779 se contrató su policromía. A este respecto se conservan tres contratos, siendo de particular interés el que firmó el pintor Vicente Alanís, en el que se especificaba que su labor sería de dorado y estofado, tanto "del retablo principal de dicho glorioso santo", como de sus "tribunas, pilastras y todo lo demás que corresponda dorar y estofar en la dicha capilla mayor”. Otro tercio lo contrató Juan Mateos del Parque y el último Francisco José Morales Fariña ${ }^{16}$. Se tiene constancia además de que el referido Morales estaba realizando su labor en 1780, pero aún en 1786 un tal José Rodríguez seguía cobrando por la misma actividad ${ }^{17}$.

La obra, en cualquier caso, es en extremo compleja de analizar, ya que hay que recordar, en primer lugar, que se vio muy afectada por el incendio intencionado de la capilla el 12 de mayo de 1931, por lo que con posterioridad fue muy intervenido, suponemos que no precisamente con los actuales criterios conservacionistas. El padre Diego de Valencina, testigo de los dramáticos hechos, narró el intento de destrucción de la iglesia, que a la postre logró salvarse. Dicho autor, que aunque resulta fuente esencial del retablo y de toda la capilla no ha sido atendido hasta ahora, especificó que cuando se reconstruyó el edificio en "el altar mayor se compuso de talla y oro el manifestador, el sagrario y la parte baja del altar,

${ }^{14}$ HERRERA GARCÍA, Francisco Javier: "Sobre la intromisión de otras artes en la arquitectura", Atrio, 4, 1992, pp. 117-129, véase en concreto las pp. 124-125.

${ }_{15}$ PLEGUEZUELO, Alfonso: Cayetano de Acosta..., op. cit., p. 111.

16 CABEZAS GARCÍA, Álvaro: Teoría del gusto y práctica de la pintura en Sevilla (1749-1835). Sevilla, 2015, pp. 428-431.

${ }^{17}$ PLEGUEZUELO, Alfonso: Cayetano de Acosta..., op. cit., p. 111. 
que con el agua y los golpes recibidos estaban sumamente deteriorados"18. No obstante, aún en nuestros días sigue muy ennegrecimiento, lo que dificulta considerablemente no ya su análisis, sino su mera visión (Figura 2).

Otra cuestión que complica el análisis de este retablo es que todo parece indicar que en él se emplearon al menos algunos elementos del anterior, el cual se levantó a finales del siglo XVII, y que parece que aún podemos ver en el actual. Así, aparte de la envarada escultura de San José que lo preside, el fundamental padre Valencina, a partir de interesantes pesquisas documentales, señala que Pedro Roldán realizó la embocadura del camarín que es una suerte de rompimiento de gloria formado por cabezas de querubines y nubes. Por otra parte, la misma fuente también nos informa de alteraciones que se llevaron en el retablo con anterioridad al incendio de la iglesia ${ }^{19}$.

A pesar de todo lo anterior y tras haber vuelto a analizar la obra con un cierto detenimiento, pensamos que su responsable debió de ser Francisco de Acosta el Mayor. Parece claro que este retablo no se debe al proyecto de Pozo, por la sencilla razón de que no es anástilo, como las fuentes señalan que era su sorprendente propuesta. De igual modo, tiene poco de los estilos de Cayetano de Acosta y de Julián Jiménez. El primero nunca llegó a este grado de magmática disolución estructural y el segundo, igualmente mucho más estructurado, se caracterizó por recamar sus obras con una menuda decoración que en modo alguno cabe identificar con la del retablo mayor de San José20 (Figuras 3-5).

Por el contrario, hay varios detalles que nos hacen relacionar este retablo con el primogénito del gran maestro portugués. En primer lugar, cabe destacar los estípites que flanquean la obra, los cuales han abandonado por completo todo su sentido geométrico inicial y se han convertido en una vertiginosa sucesión de rocallas y de molduras cóncavas y convexas en las que se mezclan ángeles. Tales estípites recuerdan mucho más a los que empleó Francisco de Acosta el Mayor en sus retablos del Carmen Calzado de Carmona que a los de cualquier otro autor de la época. En tal sentido cabe mencionar que fue habitual en los retablos de $\mathrm{Ca}$ yetano de Acosta la alternancia de estípites muy geométricos con otros más disueltos por la rocalla, nada de lo cual se aprecia en esta ocasión.

De igual manera, los derretidos soportes que enmarcan la hornacina-camarín de San José que centra el cuerpo de la obra recuerdan a los que también vemos en los citados retablos de Acosta el Mayor. En el caso del retablo de San José de

${ }^{18}$ DE VALENCINA, Fray Diego: El incendio de la capilla de San José. Residencia de padres capuchinos ocurrido en la madrugada del día 12 de mayo del año 1931. Apuntes para la historia. Sevilla, 1939, p. 33.

${ }_{19}$ Ibidem, pp. 34-35. Véase también RODA PEÑA, José: Pedro Roldán escultor 16241699. Madrid, 2012, pp. 293-294.

${ }^{20}$ Sobre Julián Jiménez remitimos a RECIO MIR, Álvaro: "El brillante final del barroco...", op. cit., pp. 355-360. 
estos soportes apenas se intuye su arranque y base, ya que son interrumpidos por esculturas, a pesar de lo cual tienen la misma proyección espacial al bies que los de Francisco de Acosta el Mayor. Verdaderamente no se trata en puridad de estípites, ya que su configuración filiforme, quebradiza y alambicada en nada evoca el sentido tectónico y formal de tales soportes. Del mismo modo, los ángeles que parecen sostener esforzadamente dichos soportes y que flanquean el manifestador de la obra, se repiten en el caso, por ejemplo, de la Fundación San Telmo.

La curvatura de la cornisa del retablo mayor de la capilla de San José es uno de sus elementos más característicos y aunque no tiene parangón con ningún retablo de la época, por su desproporcionada potencialidad y por su enloquecida dislocación en una sucesión trepidante de rectas y curvas, sería comparable con el retablo de la Virgen del Rosario que preside la capilla sacramental de San Jacinto de Sevilla, que atribuimos a Francisco de Acosta el Mayor.

Otros detalles decorativos que vemos en las obras de este autor son la aplicación de grandes golpes de rocalla, rocallas gigantes las hemos denominado, y que en esta ocasión protagonizan sus calles laterales. Tales rocallas son mucho mayores que las que vemos en los retablos de su padre y por completo opuestas a las menudas de las obras de Jiménez. También el marco de rocalla calada que rodea esta obra y que sobrepasa su lógico contorno es habitual en las obras del autor al que atribuimos este retablo.

Pero no solo a estos detalles de carácter decorativo nos remitimos para atribuir esta obra a Francisco de Acosta el Mayor. Su estructuración general, su adaptación al medio punto con el que remata la cabecera de la capilla y su ligerísimo carácter cóncavo nos recuerdan particularmente al ya referido retablo de San Jacinto de Sevilla.

Por el afianzamiento de la rocalla, verdaderamente furibunda y definitiva, y por su ingente aparato decorativo, este retablo mayor de la capilla de San José de Sevilla es claramente una obra de la década de los años sesenta o de principios de los setenta del siglo XVIII. En tal sentido, cabe recordar que el primer contrato que conocemos firmado por Francisco de Acosta el Mayo es de 1765, un desaparecido altar portátil de cuatro cuerpos para Santa María de Carmona ${ }^{21}$. Su primer retablo conservado y documentado es el ya aludido de la Fundación San Telmo, que contrató como mayor del Carmen Calzado de Carmona en 1770. En torno a esas dos fechas, las de máximo apogeo de la rocalla por cierto, pensamos que se debe fechar el retablo que ahora nos ocupa, lo que viene a coincidir con la datación que ya vimos que le otorgaba Sancho Corbacho.

No obstante, aunque pensamos que debe de ser obra suya, no podemos olvidar que Francisco el Mayor se formó con su padre Cayetano de Acosta y que él fue el fiador de sus primeras obras. No sabemos qué ocurrió en esta de la capilla

${ }^{21}$ MIRA CABALLOS, Esteban y DE LA VILLA NOGALES, Fernando: Carmona en la Edad Moderna..., op. cit., p. 133. 
de San José de Sevilla, pero consideramos muy factible que se viese apoyado por el referido taller de los Acosta en su ejecución material, factoría artística de la que tan poco sabemos hasta ahora.

En modo alguno queremos cerrar el camino a estudios más apurados que el aquí apuntado; al contrario, buscamos abrir un debate al respecto, ya que somos conscientes de que el retablo mayor de la capilla de San José de Sevilla del gremio de carpinteros de lo blanco requeriría, además de su profunda restauración, de un mayor análisis. En particular, su complejísima imaginería, que recordemos fue ampliamente intervenida tras el incendio de 1931, requeriría de una mucho más detenida atención. Sobre la misma ha señalado el tantas veces referido Pleguezuelo que tiene relación con Cayetano de Acosta, sin dejar de indicar que algunas de sus muchas esculturas "muestran calidad inferior a la obra personal del portugués". En tal sentido, hay que empezar por el titular de la capilla, obra anterior al retablo actual, ya que la hizo en 1694 Agustín de Perea. El referido historiador denota el estilo de Acosta en las dos esculturas de los santos juanes que presiden las calles del retablo y en el Dios Padre que lo corona. También impronta de Acosta ve en los seis relieves que pueblan la obra, aunque parece mantener la tradicional atribución a Duque Cornejo de la Santa Ana y San Joaquín que flanquean el camarín 22 .

Ahora bien, no nos cansamos en insistir en lo que señala el padre Valencina, que recuerda que los vándalos que quisieron acabar con el edificio, fruto de su sádica pulsión iconoclasta, cortaron las cabezas de sus imágenes. En concreto, de la imagen de San José que preside el retablo especificó que "estaba intacta cuando los incendiarios salieron de la iglesia. Luego, no sé quién, la echó a rodar desde el camarín al pavimento, quedando partida en varios pedazos y arrastrándose en su caída no poca talla del altar mayor". En cuanto al resto de las imágenes del retablo mayor indica también que "las cuatro esculturas que hay en el altar mayor representando a San Juan Evangelista, San Juan Bautista, San Joaquín con la Virgen Niña en sus brazos y Santa Ana, necesitan repararse para que no se pierdan los trozos que hoy tienen poco firmes", lo que indica su delicado estado de conservación ${ }^{23}$. Se trata por tanto de un conjunto heterogéneo de imágenes, entre las que se encuentran algunas de acarreo y de las que se realizaron ex profeso sabemos que requirieron de diversas restauraciones.

Pero si es poco lo que sabemos de Francisco de Acosta el Mayor como ensamblador, es menos lo que conocemos de su actividad escultórica. No obstante, tanto en el caso del retablo de San Jacinto, aunque solo mediante atribución, como en los laterales de la capilla del palacio arzobispal, en este caso sí documentados, contamos con algún ejemplo que nos permite compararlas con las de

${ }_{22}$ PLEGUEZUELO, Alfonso: Cayetano de Acosta..., op. cit., p. 113.

${ }^{23}$ DE VALENCINA, Fray Diego: El incendio de la capilla de San José..., op. cit., pp. 23 y 34 . 
la capilla de San Josée ${ }^{4}$. Igual que pensamos que de su ensambladura se ocuparía él, suponemos que su imaginería también debió de ser obra suya. En cualquier caso, es factible que contase con la colaboración del taller familiar, aunque el estilo de las principales imágenes de este retablo, en particular los santos juanes, en nada difieren de lo poco seguro que sabemos de su labor como imaginero. Realmente, como vimos que apuntó Pleguezuelo, el tono general de estas imágenes no alcanza la calidad de las de Cayetano de Acosta, aunque el paralelismo con ellas es evidente, como ocurre por ejemplo con el referido Dios Padre que centra su ático y que creemos antecedente claro del que luego remató el retablo mayor del Salvador.

Otra cuestión interesante de este retablo y digna de futuros estudios es la de su proyección en las tribunas y retablos que lo flanquean, que como vimos está perfectamente documentado en el caso de su policromía y prueba la irrefrenable potencia expansiva de la decoración del mismo y su capacidad para fagocitar toda la cabecera del templo. Estas tribunas no parecen haber sido levantadas por las mismas manos que el retablo mayor y evidencian una ejecución en diversas fases de nuevo con elementos de acarreo. También cabría plantearse la relación o proyección del retablo mayor con el mobiliario del templo, como sus confesionarios, sillas, bancos, florones de las bóvedas, marcos de cuadros, celosía del coro o caja del órgano, todo lo cual fue brutalmente atacado en el incendio de $1931^{25}$. Pese a ello, lo aún conservado muestra innegables concomitancias con el retablo mayor, como muestra, por ejemplo, el extraordinario penacho rococó que centra la tribuna que sostiene el coro.

Al igual que en el convento de San Jacinto en Triana, donde ademas del referido retablo de la Virgen de Rosario le atribuimos el amplio ciclo de yeserías que adornan su iglesia y sacristía ${ }^{26}$, es posible que también en el caso de San Jose, Francisco de Acosta el Mayor, además de hacer retablo mayor, interviniese en la ornamentación de la capilla, como en las rocallas que decoran su fachada, que tantas concomitancias tienen con las yeserías de San Jacinto y con el propio retablo que en esta ocasión hemos analizado. Cabe destacar en tal sentido las dos

${ }^{24}$ Sobre las de San Jacinto véase RECIO MIR, Álvaro: "La escultura sevillana, la Academia de San Fernando y el ocaso de la escuela", Academia, 104-105, 2007, pp. 133156; y sobre las de la capilla del palacio arzobispal, FALCÓN MARQUEZ, Teodoro: El Palacio Arzobispal..., op. cit., p. 145.

${ }^{25}$ Sobre este mobiliario volvemos a remitir a DE VALENCINA, Fray Diego: $E l$ incendio de la capilla de San José..., op. cit. Con Francisco de Acosta el Mayor ya fue relacionada la caja del órgano de esta capilla en CABEZAS GARCÍA, Álvaro y LUENGO GUTIÉRREZ, Pedro: "Notas sobre cajas de órganos en la Sevilla del siglo XVIII", Archivo hispalense, 267-272, 2007, pp. 205-224, véase en concreto la p. 215.

${ }^{26}$ RECIO MIR, Álvaro: "El convento dominico de San Jacinto de Sevilla", en RODA PEÑA, José (dir.): XVII Simposio sobre hermandades de Sevilla y su provincia. Sevilla, 2016, pp. 151-182. 
tarjas de rocalla que coronan las hornacinas que flanquean la puerta de la capilla, de carácter calado y muy similares a las de San Jacinto.

A manera de conclusión, cabe insistir en que el retablo mayor de la capilla de San José sería, creemos, la primera gran obra en Sevilla de Francisco de Acosta el Mayor, que se convirtió poco después en el gran ensamblador de la ciudad, en los años ochenta del siglo XVIII, al suceder a su padre incluso en la maestría mayor de talla del arzobispado hispalense, lo que le permitiría extender su influencia a tan amplísimo marco artístico, tanto por lo que se refiere al ámbito del retablo como al de la decoración en general ${ }^{27}$.

En cualquier caso, en esta obra el rococó sevillano alcanzó su máximo apogeo, siendo paralelo a lo que en el caso novohispano se ha calificado expresivamente como "retablo anástilo" o "ultra barroco" 28 . De sorprendentes cualidades plásticas, el retablo mayor de la capilla de San José muestra un desideratum ornamental que por completo disuelve las lineas estructurales que articulan su ensambladura. Pero no solamente se trata de una cuestión decorativa, la violenta prominencia espacial de su calle central, el rompimiento de gloria que enmarca el expositor que se dispone sobre su sagrario, los estudiados planos que dan profundidad a su hornacina central hasta convertirla en un camarín virtual, la arracimada sucesión de ángeles y querubines que anidan en su quebrada estructura, el movimiento que trepida tanto su imaginería como sus golpes de talla rococó, su expansión física en la capilla mayor y aún en todo el temblo, la brillante y colorista policromía que todavía se intuye bajo la densa capa de hollín y polvo que lo cubre por completo y, en una palabra, el ánimo barroco que parece dar vida a todo ello, hacen sin duda de esta obra única una de las cumbres del retablo sevillano.

Fecha de recepción: 19 de octubre de 2018

Fecha de aceptación: 5 de febrero de 2019

${ }^{27}$ ROS GONZÁLEZ, Francisco Sabas: Noticias de escultura..., op. cit. p. 14; y AMORES MARTÍNEZ, Francisco: "Artistas y artesanos al servicio de los arzobispos de Sevilla. Algunas noticias sobre sus maestros mayores", Anuario de historia de la Iglesia andaluza, 9 , 2016, pp. 259-271, véanse en concreto las pp. 264, 265 y 271. En tal sentido, aunque no vayamos ahora a analizarlos, no queremos dejar de apuntar la relación que vemos con Fracisco de Acosta el Mayor y los dos retablos que se levantan a los pies de la parroquia de San Esteban de Sevilla, dedicados a San José y Santa Ana, ya muy cercanos al neoclasicismo. Sin duda, su labor en la implantación de dicho estilo es una cuestión digna de futuros estudios.

${ }^{28}$ Véase en tal sentido VARGAS LUGO DE BOSCH, Elisa: "Ultra barroco o anástilo", Artes de México, 106, 1968, pp. 58-68. 


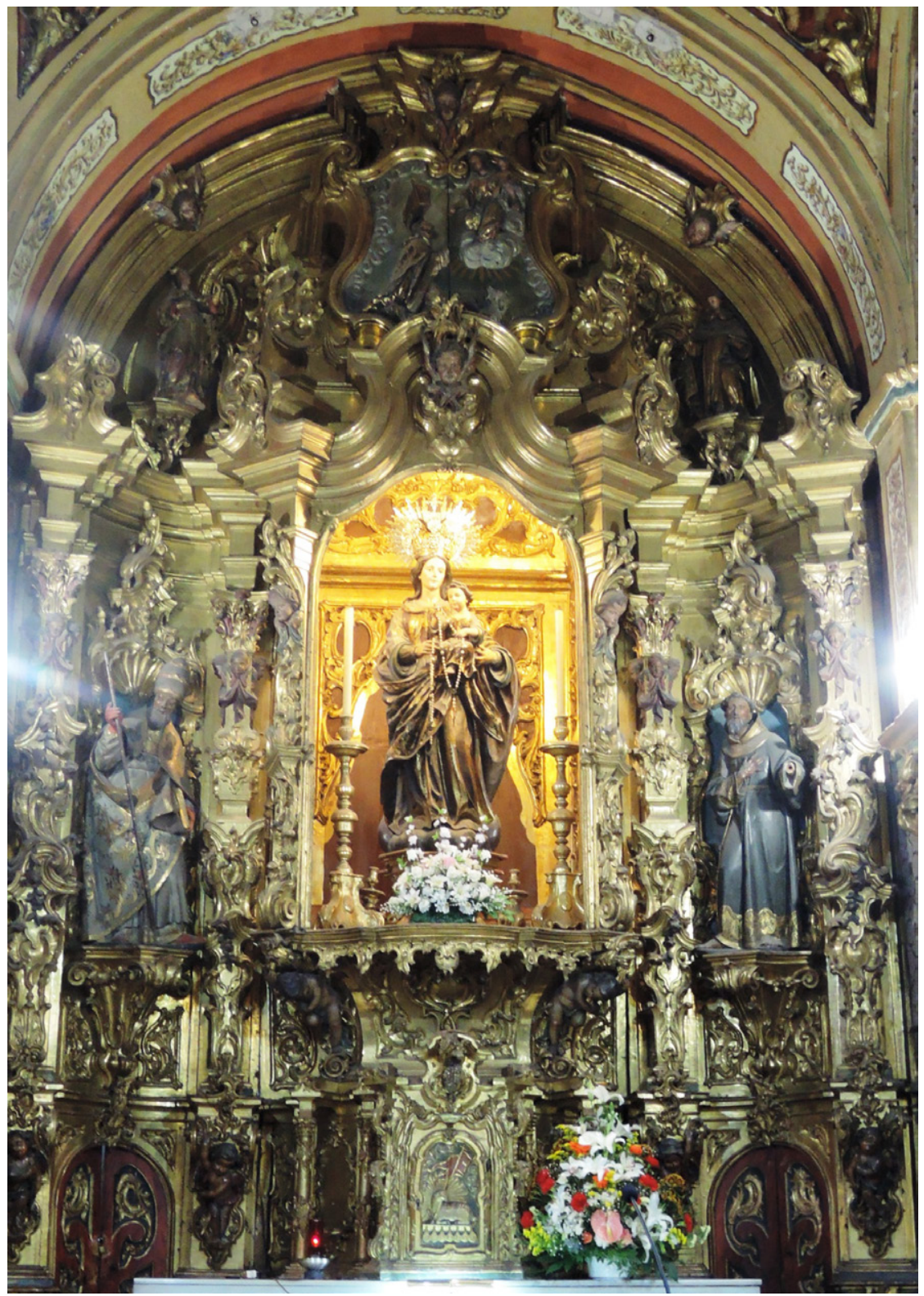

Figura 1. Francisco de Acosta el Mayor (atribución), Retablo de la capilla de la Virgen del Rosario, hacia 1775, iglesia de San Jacinto, Sevilla. 


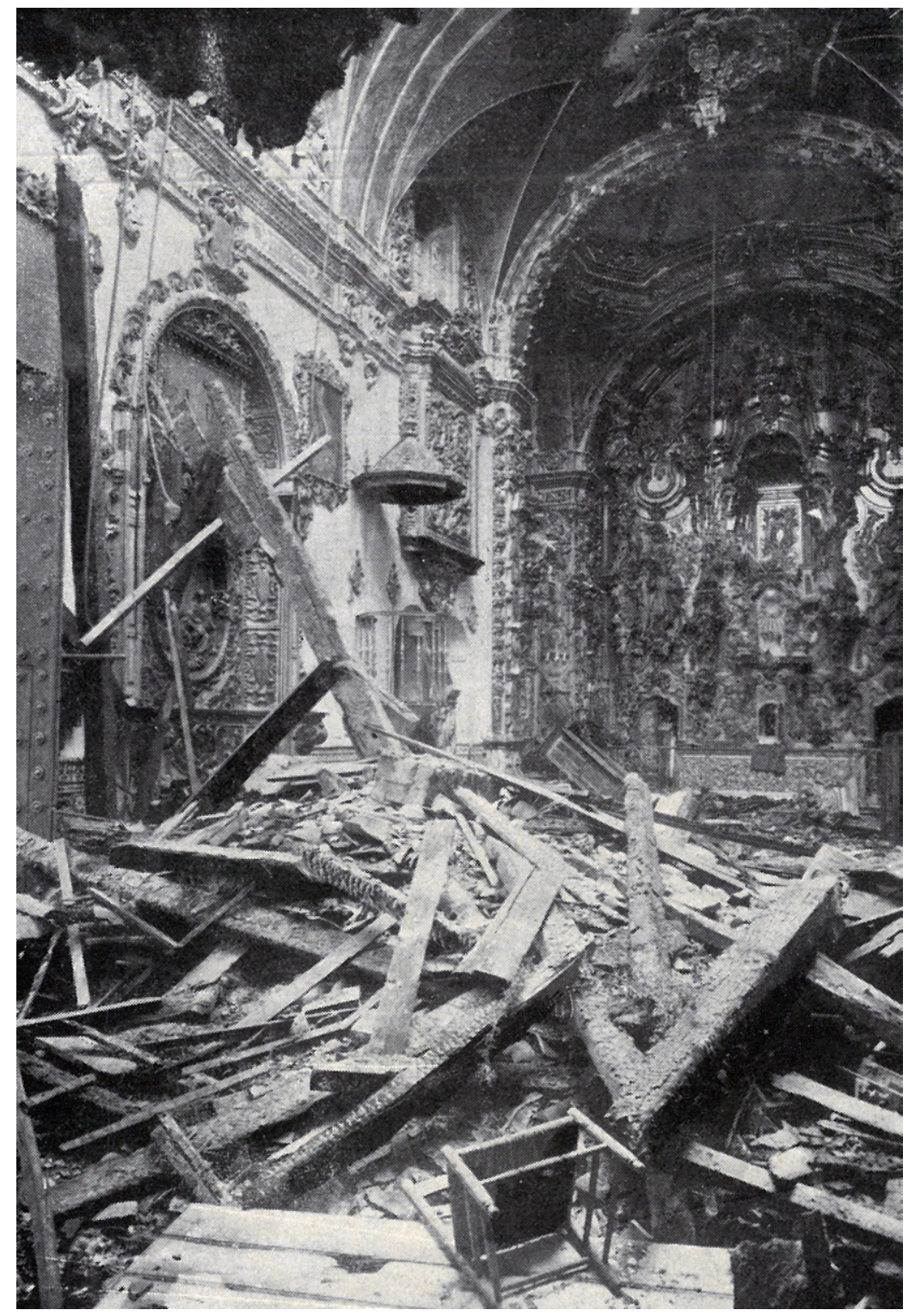

Figura 2. Capilla de San José tras el incendio intencionado de 1931. 


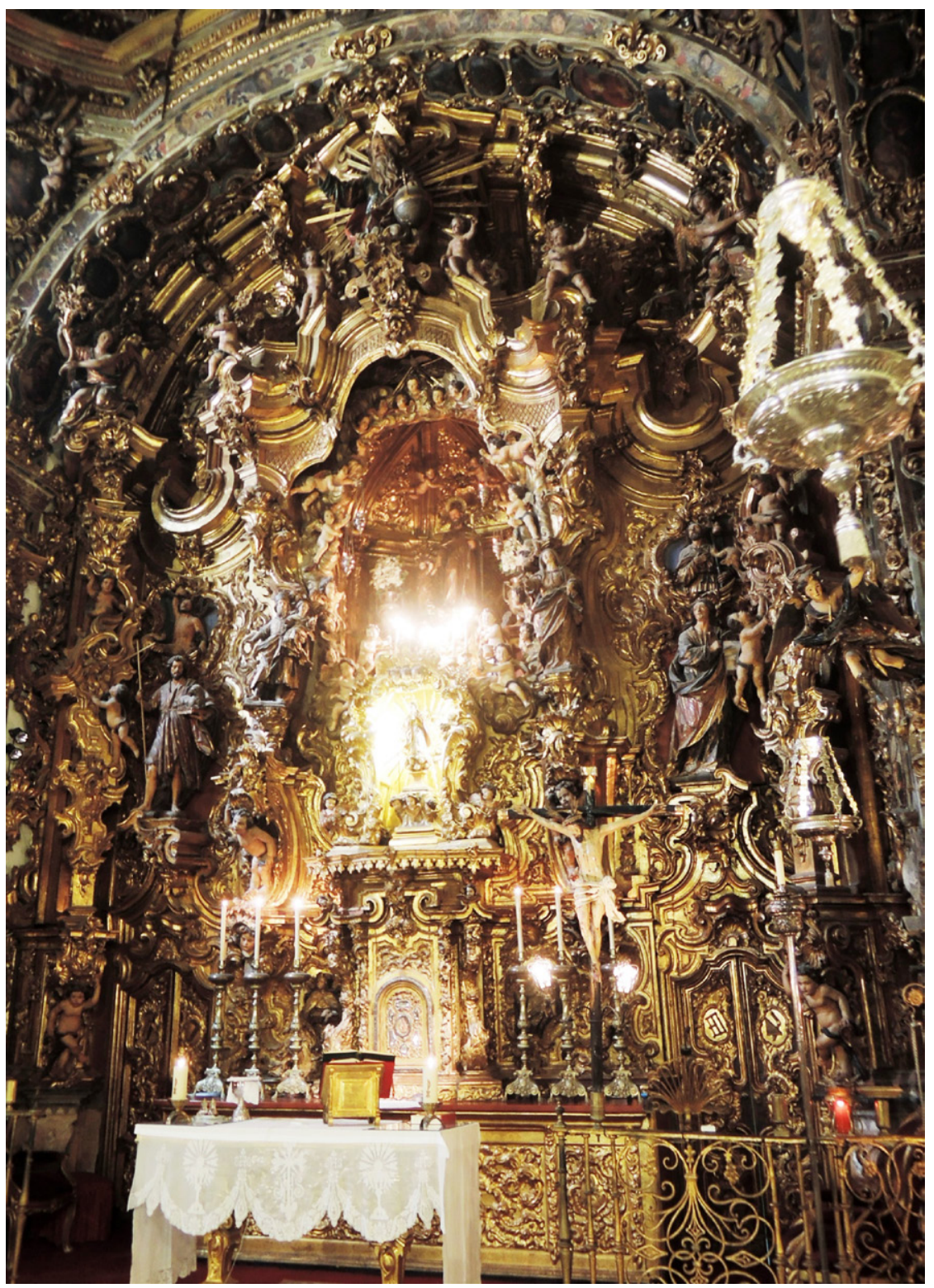

Figura 3. Francisco de Acosta el Mayor (atribución), Retablo mayor, hacia 1765-1770, capilla de San José, Sevilla. 


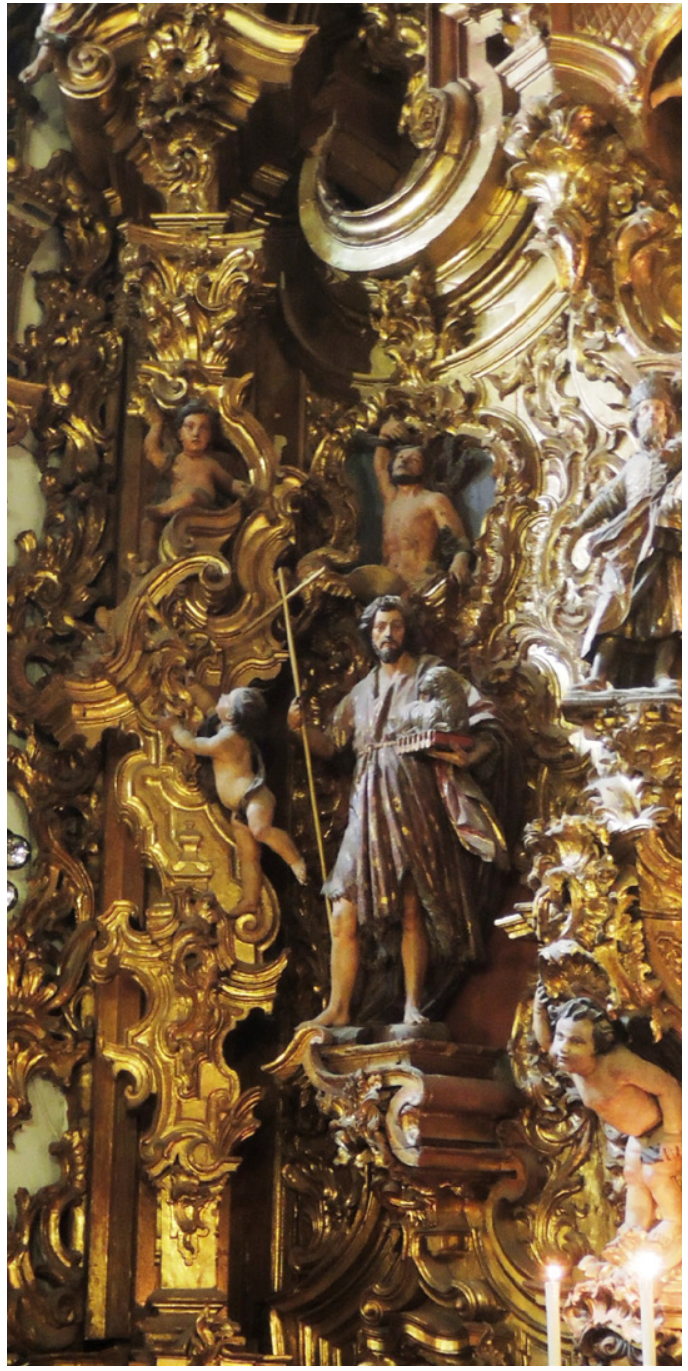

Figura 4. Francisco de Acosta el Mayor (atribución), Retablo mayor (detalle), hacia 1765-1770, capilla de San José, Sevilla.

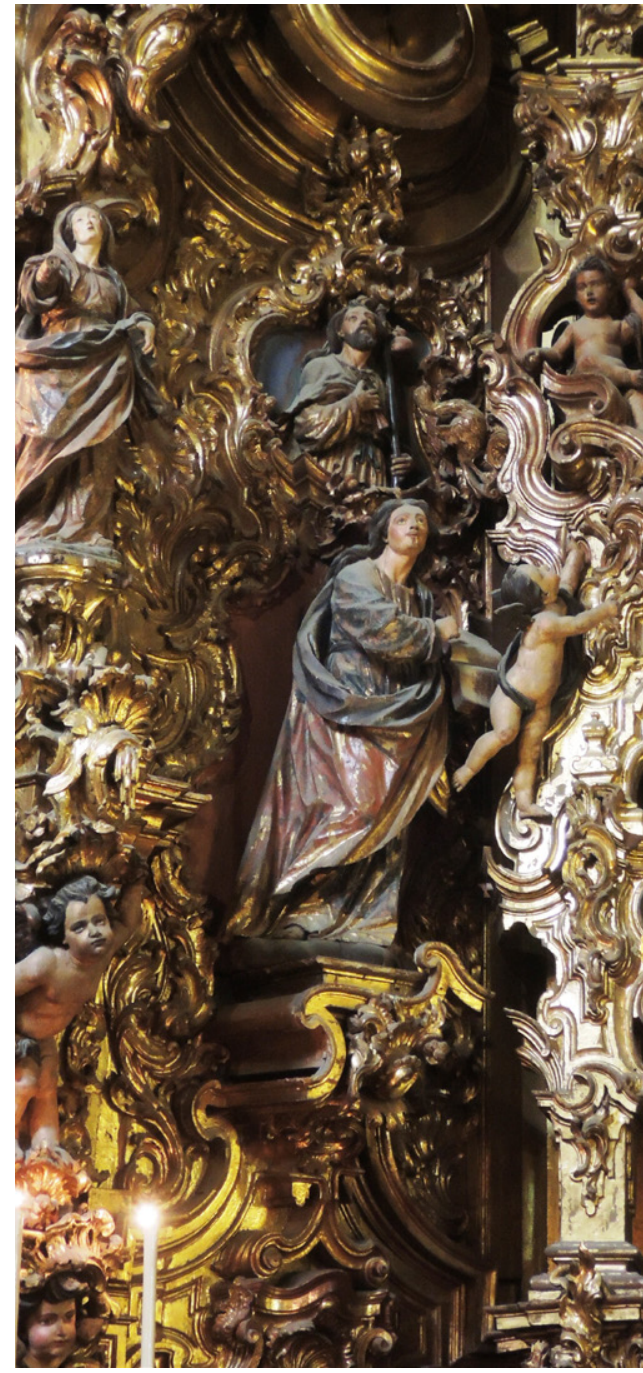

Figura 5. Francisco de Acosta el Mayor (atribución), Retablo mayor (detalle), hacia 17651770, capilla de San José, Sevilla. 